\title{
Main characteristics of Hungarian-Croatian political relations and Cross-Border Co-operations
}

\author{
Szilárd Rácz ${ }^{\mathrm{A}}$ \\ Received: December 22, 2016 | Revised: February 13, 2017 | Accepted: March 24, 2017
}

DOI: 10.18421/GP21.01-05

\begin{abstract}
The objective of the study is to present the main features of Hungarian-Croatian political relations and cross-border co-operations with a focus on the past 25 years. The study will discuss the various eras and specifics of Hungarian-Croatian political relations, the features of the borderland and cross-border relations, the spatial structural and infrastructural bases of the co-operation and the hard and soft factors of relations. The maintenance of the historically rooted relations - eight centuries of personal union, a rare example of a millennium of peaceful coexistence in Central Eastern Europe is more or less visible. Notwithstanding, coexistence between the two nationalities did not transcend the religious and cultural sphere, in most respects they only shared a common territory with each other. During the past 25 years, both Hungary and Croatia have witnessed a profound change in their perception of borders and neighbourhood relations. A new period began with Croatia becoming an autonomous state, the era of state-building characterised by inward orientation. Croatia has embarked on the road towards Euro-Atlantic Integration as a symbol of its new orientation at the turn of the millennium, which exerted a strong impact on the perception of borders and effective co-operation, while there has been a gradual deepening of Hungarian-Croatian relations. A period was concluded with the EU accession of Croatia, henceforth co-operations are established between two EU member states. This, however, does not imply positive practices in all cases. The MOL-INA affair transcending the internal corporate sphere severely damaged interstate political relations, deteriorating further with the 2015 refugee crisis.
\end{abstract}

Keywords: Croatian, Hungarian, political relations, cross-border co-operations, geopolitics

\section{Introduction}

Notwithstanding its territory, Hungary is characterised by a remarkable diversity of borders and neighbours in Europe. Its seven neighbours include an old EU member state (Austria), new EU member states with internal EU borders (Slovenia, Slovakia), new EU member states with Schengen borders (Croatia, Romania), a pre-accession country (Serbia) and a third country (Ukraine). Viewed from a larger perspective, Hungary has both western and post-socialist neighbours. As a historical heritage a smaller or larger Hungarian ethnic minority populates each neighbouring country. Since five countries achieved their autonomy during the past 25 years, producing a variety of postYugoslavian, post-Soviet and post-Czechoslovakian states, due to their delicate nature these relations demand special foreign policy activities and heightened sensitivity. This diversity is a special feature of the relations at various levels (diplomacy, politics, economy, culture, everyday life, etc.), the various challenges give rise to different responses and attitudes even though the Euro-Atlantic Integration provides a relatively narrow scope for them. Optimally it is the mutual interest of the two neighbouring European coun-

A Institute for Regional Studies, Centre for Economic and Regional Studies, Hungarian Academy of Sciences; Papnövelde str. 22, 7621 Pécs, Hungary; szracz@rkk.hu 
tries to develop multi-layered and good relationships with one another. This is especially true in case they are united by a historical heritage without a negative connotation. From a state law perspective, the most durable relations can be detected between Hungarian-Croatian parties. The period of the commonwealth lasted from 1102 until 1918 and albeit it encountered several difficulties and transformations, with the exception of a brief interlude (1848-49) it was mainly characterised by peace. The coexistence of the two nations can be detected in religious and cultural terms, while from other aspects they only shared a common space with each other.

\section{Study area and methods}

The study, according to the specifics of border research, draws on the toolkit, methodological and professional terminology (press analysis, statistical data analysis, absorption of literature, document analysis) of multiple scientific disciplines (political geography, political science, regional studies). The study classifies border regions as functional units which can be regarded as the political, social, economic etc. outcome of the border effect. This is where the problematics of delimitation stems from since the border region cannot be conceptualised in linear terms due to the abundance and complexity of the examined and determining factors, in contrast with state borders, for instance. The evaluation of the examination of the border situation and cross-border relations is a normative issue. It relies on the spatial concepts and spatial constructions of users (Paasi, 2012; Fábián, 2013). The perception of borders has undergone significant changes during the past 25 years in Hungary and Croatia as well. EU accession and integration have exerted a particularly strong impact on ideas on borders and the practice of co-operation, due primarily to the organic integration of cross-border co-operation into EU Structural Policy. Within Europe and along the external frontiers of the EU the various forms of cross-border cooperation (such as Euroregions) became widespread, while they were promoted by the $\mathrm{EU}$ as an efficient instrument of European community-building and identity formation. The ideas on borders were slowly evolving, cross-border co-operation as a phenomenon has become a symbol of European political community, EU integration and common values (Scott, 2013). As a result of the opening of borders, collaboration between various functional units such as cross-border labour-markets and cross-border urban areas has also strengthened. The notion of cross-border co-operation is enriched by a special geopolitical, minority policy element in both Hungary and Croatia (Hajdú, Nagy, 2006).

\section{Discussion and Results}

\section{The historical periods and current specifics of Hungarian-Croatian political relations}

The standard of Hungarian-Croatian relations and state borders can be divided into distinct periods in terms of public legal frameworks (Sokcsevits, 2011). Gulyás and Bali (2013) distinguish six periods, Čelan (2014) mentions seven, while Lörinczné lists four (2015). These can be divided and summarised as follows:

- Initial phase until 1102 (autonomous countries in the 10-11th centuries);

- 1102-1918 (personal union), more specifically

- 1102-1526 (unified state: Kingdom of Hungary);

- 1527-1868 (Habsburg Monarchy);

- 1868-1918 (the period of Austria-Hungary and the Croatian-Hungarian Compromise);

- 1918-1991 (era of the South Slav state), more specifically

- 1918-1941 (Kingdom of Serbs, Croats and Slovenes 1918-1929; Kingdom of Yugoslavia 1929-);

- 1941-1945 (Independent State of Croatia);

- 1945-1991 (Second Yugoslavia);

- The current phase from 1991 onwards (Autonomous Croatia).

The study focuses only on the relations characteristic of the latest era which can also be divided into subperiods to provide points of orientation.

- The first phase (1991-1999) marks the first decade of independent Croatia. A new era began with Croatia becoming an independent state, characterised mainly by inward orientation. This period of state-building, the state-nation, or from another approach, that of war, was characterised by special transborder movements.

- The second phase (2000-2013) began at the turn of the millennium- with the changing orientation following the death of President Franjo Tuđman. This coincided with the beginning of Euro-Atlantic Integration in Croatia, and its most intensive phase in Hungary. Both countries focused on their western partnership relations. There has been a gradual deepening of bilateral relations.

- The third phase (2013-) began with the EU membership of Croatia, henceforth, co-operation has evolved between two EU member states. This, however, did not necessarily imply a positive shift. The global economic crisis of 2008 had a severe impact on interstate relations (particularly the MOL-INA-affair), which were further aggravated by the 2015 refugee crisis. 
The bilateral relations began to form during the era of SFRY. During his trip to Yugoslavia in June 1990, foreign minister Géza Jeszenszky visited Zagreb where he opened the Consulate General of Hungary and conducted negotiations with members of the Croatian political elite as well. Albeit the dismantling of Yugoslavia, the Hungarian arms export scandal, the sharpening conflict and the Hungarian response (strengthening border control) generated a tense situation, the official visit of Franjo Tuđman to Hungary took place already on 19 April. The President of Croatia guaranteed the rights of the Hungarian ethnic community and Hungarian public law dignitaries also reached an agreement on the issue of the autonomy of South Slav nations (Jeszenszky, 2002; Juhász, 2011; Lőrinczné, 2015). The declaration of independence (June 25, 1991) and the eruption of the civil war produced a new situation from the perspective of Europe as well (EC Declaration, 27 August, 1991). Hungary urged international intervention, since besides the issue of the autonomy of Croatia, it also had to take into consideration the situation of Hungarians living in Vojvodina. Thus, Hungary acknowledged the independence of Croatia at the same time as the EC, on January 15, 1992 (Bali, 2012a). Shortly afterwards, Consulates General were raised to the rank of Embassy and signed a Treaty on friendly relations and cooperation between the Republic of Hungary and the Republic of Croatia on December 16, 1992 (Basic Treaty, 1992). Partnership relations were constantly developing, the Hungarian-Croatian Basic Treaty was followed by several significant documents: Convention between the Republic of Hungary and the Republic of Croatia on the Protection of the Hungarian Minority in the Republic of Croatia and the Croatian Minority in the Republic of Hungary (1995); Protocol on the legal succession of the Republic of Croatia in the international treaties between the Republic of Hungary and the SFRY (1996), visa waiver agreement (2000), Free Trade Agreement (2001). Following the opening of embassies (1992) diplomatic ties were gradually extended, Honorary Consulates were established in Rijeka (1997), Split (2001), Dubrovnik (2014), a Consulate General was opened in Osijek (2002-2006, reopened: 2013). A Croatian Consulate General was established in Pécs (1995) and a Honorary Consulate in Nagykanizsa (1999). Meetings between state leaders have become frequent. The intensity of relations was boosted by the launching of EU accession negotiations in Croatia. Joint government sessions - a new practice among post-Socialist states - constituted a new quality element in the relations (Budapest, January 26, 2006; Zagreb, May 17, 2007; Barcs, September $17,2009)$, within the framework of which several bilateral declarations were signed. The intergovernmental mixed committees are responsible for the coordination of tasks, inter-ministerial consultations were conducted on a regular basis and by the end of 2009, a Cross-Border Regional Coordination Forum had also been set up.

Developing and prioritising Croatian-Hungarian relations has been a permanent objective of Hungarian governments, benefiting from the support of successive opposition parties as well (Lörinczné, 2015). Hungary has been among the supporters of the Euro-Atlantic Integration of Croatia. Besides Germany (the first to acknowledge Croatia) and Austria (which essentially forced the launching of the negotiations on the EU accession of Croatia), the role of Hungary must also be highlighted (which was the first to ratify the NATO accession of Croatia and under whose presidency EU accession negotiations were terminated). Concerning state boundaries, it is worth noting that Croatia - with the exception of Hungary - has conflictual issues with each of its neighbouring countries: the Neum Corridor with Bosnia-Herzegovina, Prevlaka peninsula with Montenegro, the Danube border with Serbia (Šarengrad), the exit to the sea with Slovenia (Piran Bay). The still unsettled Slovenian-Croatian border debate halted the EU accession of Croatia for a long time.

International relations and ratified international treaties provide the framework of bilateral co-operation. Based on the analysis of interstate agreements and political meetings, currently the main elements of Hungarian-Croatian relations are as follows:

- political, diplomatic relations,

- economy,

- infrastructure and energy policy,

- ethnic minorities,

- culture and science,

- environment and tourism,

- cross-border co-operation in the immediate proximity of the state border.

\section{The borderland and cross-border relations}

The investigated border region (Figure 1) regarded as the central area of the Mura-Drava-basin constitutes an organic unity in terms of natural geography, therefore it demonstrated a spatial coherence several times in history (Nagy, 2013). The state, political, public administrative frameworks interpreted and transformed this relation in a context-specific way, particularly regarding the "movement” or functions of borders and the demographic historical processes. The quality of borders has changed on several occasions and to a significant extent over the past one-and-a-half centuries, mostly during periods of war and the subsequent „settlements". Therefore, border situation in the region 


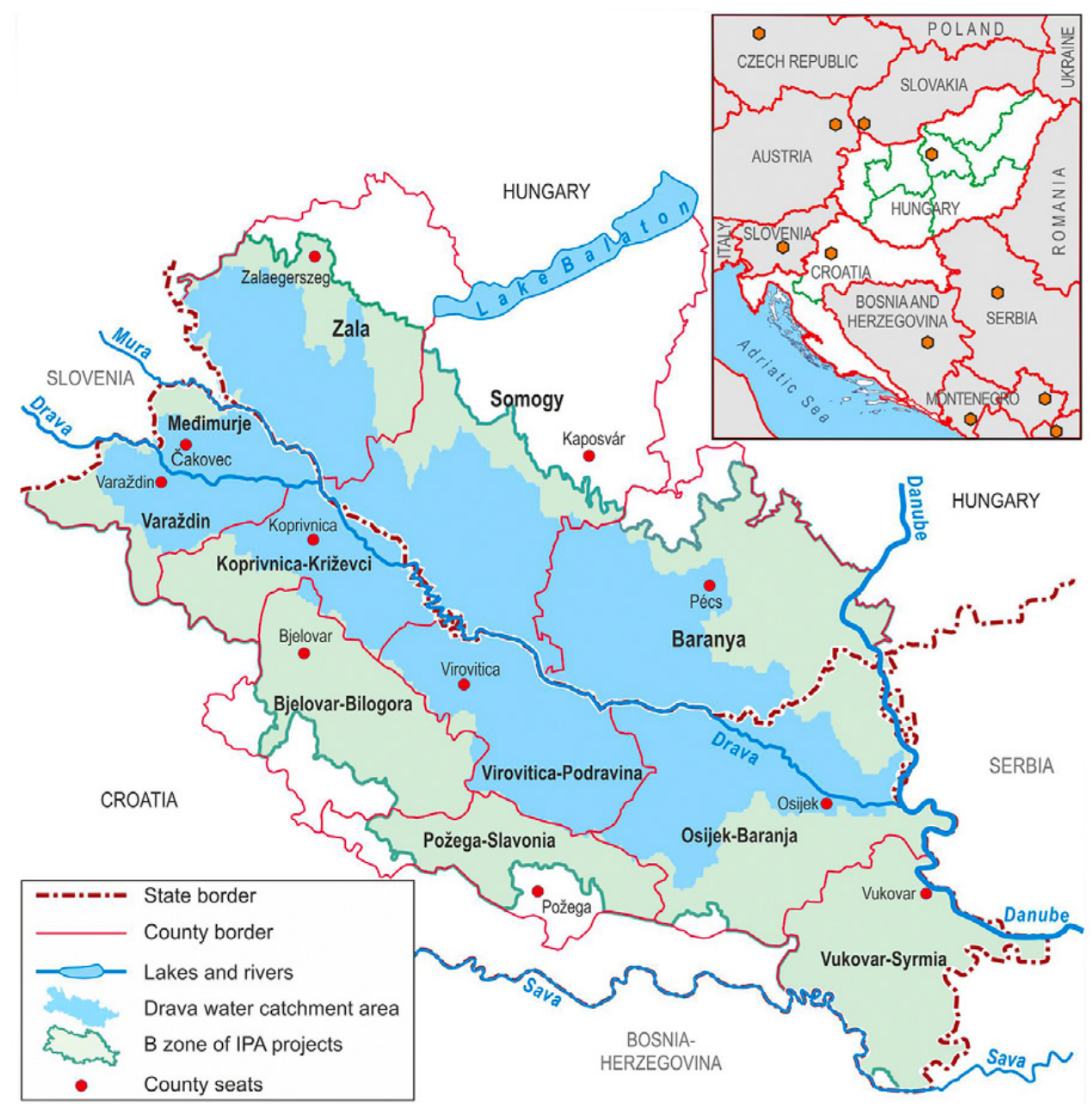

Figure 1. The Croatian-Hungarian border region Source: Author's construction based on Suvák, 2014, 6-7.

can be defined as a common asset with all the positive and negative consequences that entails.

The independence of Croatia marked a new era in the bilateral relations between the countries. Hungary's partially explicit and partially implicit support of the independent state of Croatia has created new opportunities for conducting bilateral co-operations. In general, the period was characterised by a certain inward orientation, marked by the formation of the state of Croatia and the patriotic war. The political, economic, social transformation processes surrounding the regime change in Hungary have also marginalised previous economic relations. Hungarian-Croatian political relations were settled by the basic treaty signed at the end of 1992, inter-ministerial conciliations, meetings of foreign ministers and state secretaries were generalised. Hungarian large companies penetrated the Croatian market. However, cross-border traffic diminished and its structure was transformed. The situation of various parts of the Hungarian-Croatian border section was diverse (the border section is usually divided into three distinct parts along the Drava). Special transborder movements characterised the region due to the civil war. The Serbs closed the total length of the land border in the Baranya-triangle, filled it with mines, the border crossing of Udvar was not opened until 1998. The operation of Drávaszabolcs was maintained on an almost permanent basis, the role of Barcs and especially Letenye has been upgraded. In 1991-1992 Baranya became a host area to refugees, imposing a heavy burden on towns situated at the proximity of the border and Pécs in particular. The proportion of Hungarians in cross-border traffic significantly diminished, Hungarians tended to profit from the border crossing in Letenye. The rate of Croatian inward and outward passengers augmented due to the shortage economy. The retail sales of towns situated in the proximity of the border showed a significant increase, according to various estimations, Croatian shopping tourism accounted for almost $30 \%$ of the total guest turnover, and $70 \%$ in the case of various products. Consequently, several companies were established in the Hungarian part of the borderland, foreign trade companies were mostly formed by refugees. The optimal (and in most cases illegal) exploitation of the border economy has become a major source of income for many (Hajdú, 1996, 2004). 
The civil war caused a serious damage in Croatia, and it was not until 1998 that the situation became somewhat normalised. This facilitated a more diversified extension of Croatian-Hungarian cross-border relations. Regional linkages were reinvigorated (creation of Euro- regions) and the revival and extension of sister city relationships could also be observed. The development of interstate political relations served as the main driving force, prime ministers declared strategic partnerships, a free trade agreement was established, a document about setting up an intergovernmental joint committee was signed. Croatia committed itself to the Euro-Atlantic Integration at the turn of the millennium, which brought about a significant orientation shift. The European Union became a major player in the relationships of the area which was not solely due to the available funding opportunities. The detection of potential cross-border relations occurred and the extension of linkages was launched in several areas. The beginning of the period of European Integration did not entail either the permanent deepening of cross-border relations or their significant intensification in the deeper structures (Bali, 2012a, 2012b; Lörinczné, 2014, 2015). The reasons behind the failure to create an integrated border region are manifold. On one hand, the two countries turned westwards, both states devoted more energy to becoming integrated into the European core area, which highlighted the role of central areas dominated by capital cities. On the other hand, the immediate cross-border territories belonged to the category of poorer regions in both countries, thus their spatial structural assets and economic potential did not foster the optimal development of the cooperation, nor did the ethnic pattern of the border region. Thirdly, several factors are required for the generation of these relations as has been demonstrated in the case of the more advanced Austrian-Hungarian-Slovakian border region (Hardi, 2008; Lőrinczné, 2011, 2013; Nagy, Romelic, 2013).

The EU accession of Hungary in 2004 signified a progress in interstate political relations. Croatia also entered the pre-accession phase and was supported by Hungary from the very beginning. The first joint governmental session in 2006 implied a qualitative advancement. The highest-level forum designated numerous general (Euro-Atlantic partnership, development of bilateral relations, the distinctive treatment of minorities, cross-border co-operations) and some concrete (infrastructural) directions of the cooperation. The Hungarian-Croatian Chamber of Commerce and Industry was established on May 24, 2006 in Zagreb. The following years included several significant elements to be highlighted in the evolution of the cooperation predominantly related to culture.
Such were the joint but unsuccessful Hungarian-Croatian football EC project, the establishment of the Hungarian Department at the Josip Juraj Strossmayer University in Osijek, and the partnership with Croatia in the Pécs European City of Culture project (Southern Cultural Zone). Certain visions were transformed into tangible results in the realm of culture. From the aspect of the partnership it was emblematic that the EU accession negotiations with Croatia were terminated on the last day of the 2011 Hungarian EU Presidency. With the EU membership of Croatia, the Croatian-Hungarian partnership became the focal point of attention in the summer of 2013 once more, in Hungary the public opinion was mostly concerned with its economic and social consequences and the various views. The immediate border region benefited from the removal of mines from the common border section in the Baranya-triangle through EU financing. To sum up, it can be declared that the complex political, infrastructural and institutional conditions of cross-border co-operations were developed in a period of two decades (Hajdú, et al., 2013).

Unfortunately, both countries were severely affected by the global economic crisis. The chaotic situation of new market economies damaged individual, corporate and interstate political relations as well. The MOLINA-affair transcending the internal corporate sphere over the past few years is merely a symptom of a phenomenon produced by interests working against European territorial cooperation. It cannot be declared with absolute certainty whether nationalism, protectionism, superpower geopolitics or forced path seeking attempts of small states are the underlying causes. It would be difficult to foresee the consequences of the responses triggered by the new challenges. The impacts of the refugee crisis were particularly severe during the year 2015 . The consequences of the refugee crisis have resulted in profound changes both in internal policy and bilateral relations, giving birth to and launching a plethora of novel processes. The press releases mentioned hereafter serve to illustrate the above:

- „We are neighbours, and both members of the European Union; but as our political relations are at a bottom low, this also affects our entire system of relations." (Press conference of Péter Szijjártó and Tomislav Karamarko, July 9, 2015).

- „International traffic restarted towards Austria, suspended to Croatia" (MÁV Zrt. Communications Directorate, September 29, 2015).

- „Hungarian-Croatian relations have never been as bad as they are currently, and accordingly the tremendous task awaiting both governments is to raise bilateral relations from this low." (Press conference of Miro Kovač and Péter Szijjártó, February 2, 2016). 
- „Railway traffic between Hungary and Croatia restarted... However trains are still not running through the border station at Magyarbóly" (MÂV Zrt. Communication Directorate, March 7, 2016).

\section{The spatial structural and infrastructural foundations of the co-operation}

Undoubtedly, the development level and spatial configuration of the contact zone are of outstanding significance from the aspect of cross-border cooperation. The immediate zone of the Hungarian-Croatian border section is underdeveloped in European and national terms as well (during the 2oth century, no investments were undertaken due to security policy reasons). The demographic processes are unfavourable even in light of the national average (only the data on Međimurje show a positive divergence from this tendency), the significant loss of population, outward migration and aging are phenomena observed on both sides of the border. The state of the labour market is also unfavourable, the rate of inactive and unemployed population is high. Albeit wages are higher in Croatia, this is accompanied by long-term unemployment which indicates the inflexibility of the labour market. Qualified labour force would be the key, however, the border region is in a disadvantageous position in terms of the rate of people with a secondary or higher educational qualification as well (Rácz, 2014; Suvák, 2014). Among the spatial structural characteristics it is worth noting that the area is situated at the intersection of peripheral areas characterised by a loose urban network dominated by small rural villages and a lack of functional cities coupled with the presence of a fluvial frontier serving as a dividing boundary along the majority of the border section (Figure 2).

The peripheral position of the area has historical roots and explains its weak economic performance. In terms of gross domestic product, GDP per capita values in the border region are one-third below the national average. The availability of business or financial services producing higher added values is an even more significant factor (Horeczki, 2014; Kovács, 2014). Cross-border co-operation in the immediate proximity of the state border can only be detected in two areas, Barcs-Virovitica and the Slovenian-Croatian-Hungarian tri-border area (Bali, 2010). Consequently, the predominance of co-operation between relatively remote nodes - big cities characterises the border crossing axes, which highlighted the ability of big cities to obtain project funding. The nature of the co-operation is influenced by the relatively small size of the countries in question and their centralised state organisation dominated by the capital city. Interstate political

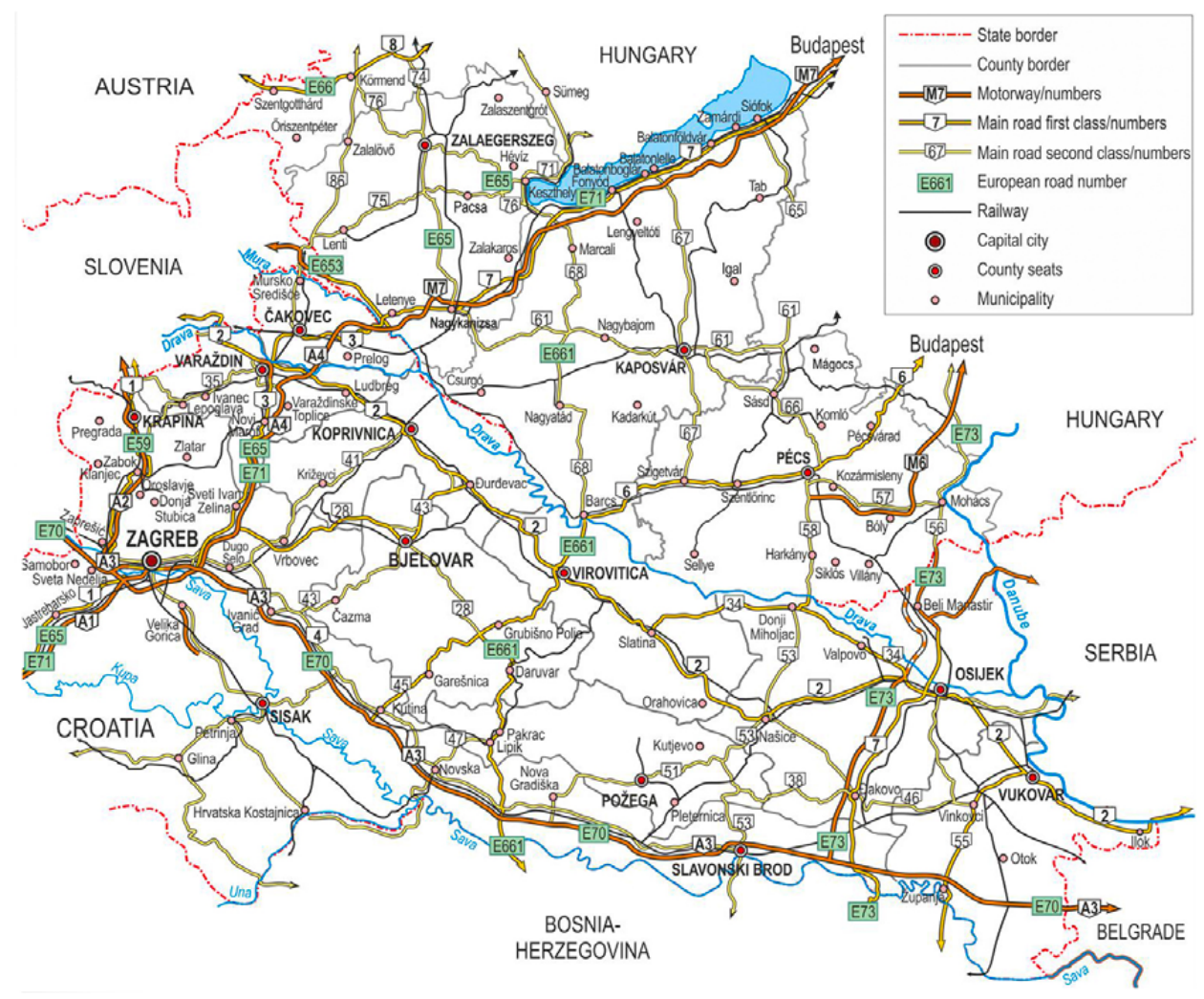

Figure 2. Transportation infrastructure, 2014

Source: Suvák, 2014, 14. 
Table 1. Public road border crossings, 2013

\begin{tabular}{|l|c|c|c|c|c|}
\hline Border section & $\begin{array}{c}\text { Length of } \\
\text { border sections }\end{array}$ & $\begin{array}{c}\text { Number } \\
\text { of current } \\
\text { relationships }\end{array}$ & $\begin{array}{c}\text { Density based } \\
\text { on current } \\
\text { relationships }\end{array}$ & $\begin{array}{c}\text { Number of } \\
\text { possible new co- } \\
\text { operations }\end{array}$ & $\begin{array}{c}\text { Density based on } \\
\text { the possible new } \\
\text { co-operations }\end{array}$ \\
\hline Hungarian-Slovak & $645 \mathrm{~km}$ & 34 & $19 \mathrm{~km}$ & 56 & $7 \mathrm{~km}$ \\
\hline Hungarian-Ukrainian & $135 \mathrm{~km}$ & 5 & $27 \mathrm{~km}$ & 16 & $6 \mathrm{~km}$ \\
\hline Hungarian-Romanian & $448 \mathrm{~km}$ & 10 & $45 \mathrm{~km}$ & 56 & $7 \mathrm{~km}$ \\
\hline Hungarian-Serbian & $164 \mathrm{~km}$ & 6 & $27 \mathrm{~km}$ & 23 & $6 \mathrm{~km}$ \\
\hline Hungarian-Croatian & $352 \mathrm{~km}$ & 7 & $50 \mathrm{~km}$ & 37 & $8 \mathrm{~km}$ \\
\hline Hungarian-Slovenian & $100 \mathrm{~km}$ & 9 & $11 \mathrm{~km}$ & 20 & $3 \mathrm{~km}$ \\
\hline Hungarian-Austrian & $349 \mathrm{~km}$ & 31 & $11 \mathrm{~km}$ & 34 & $5 \mathrm{~km}$ \\
\hline
\end{tabular}

Notes: Density = Number of border crossing points / Length of border section.

Source: Egyházy, 2013.

relations, as has already been pointed out, are essential from the perspective of cross-border relations.

The evolution of the permeability of borders is an outstanding factor from the aspect of cross-border relations. The conditions of transportation, the nature of borders, „technical” data related to border crossing points, the quality of the border (attitude of the state, border traffic, role of transit) are all factors constitutive of permeability. The Croatian-Hungarian border section is internal to the EU and a Schengen border at the same time. Bilateral declarations include plans to extend the cross-border transportation magistrals. The land border section is characterised by a relative scarcity of border crossings. There are even less border-crossing facilities across the Drava. Table 1 illustrates that among the border sections of Hungary, the Croatian section is and will be characterised by the lowest densities even following the realisation of the planned developments.

Regarding the main transportation magistrals, only capital cities have been connected by a motorway network so far. The Hungarian mid-term development objectives were announced during the governmental session in Kémes on April 25, 2013 (Governmental Decree1270/2013, Decision of the Prime Minister No. 21/2014):

- Construction of M6 motorway until the state border (section between Bóly-Ivándárda, new Drava bridge) terminated by December 31, 2018,

- Initiation of the construction of M6o motorway until the state border (Pécs-state border section) by 2020 ,

- Beginning the construction of highway no. 67 until the state border (Szigetvár-state border section, new Drava-bridge) by 2020,

- Development of ferry traffic between Vejti and Podravska Moslavina.

Similar densities of border crossings (Figure 3) can be observed in the case of the Serbian and Bosnian border section of Croatia where the Danube and the Sava fulfil an equally significant role of a dividing boundary. Comparing these with the Slovenian-Croatian border section, these latter are characterised by a significantly higher density and permeability, which indicates the perennity of economic, kinship etc. ties developed within the framework of former Yugoslavia, and at the same time, the presence of a strong transit potential.

The border crossings of Hungarians render the identification of specific types of transborder "movements" possible. The most spectacular and significant on the basis of frequency is evidently the marine connection dominated by the summer season implicating more lengthy tourism flows. Rijeka represents a permanent but insignificant relationship, since it does not fulfil a major role in the Hungarian trade in goods (since during the past two decades, Hamburg and Koper became the two major marine harbours facilitating Hungary's access to the sea). The proportion of trade in goods is low in comparison with other border sections of Hungary, heavy goods traffic is mostly realised in the form of transit traffic along specific border crossings (via public road in Letenye and railway in Gyékényes). The rest of the traffic of persons shows a more diversified pattern.

\section{The "hard" factors of relations: economy, cross-border co-operation, tourism and environment}

In addition to the previously mentioned factors of transportation (TEN-networks, motorways, public road and railway connections, bridges and border crossing points), infrastructural developments related to energy policy are also worth highlighting: the connection of power lines (in 2010), a bi-directional hydrocarbon transit pipeline (gas interconnector) in 2011, the construction of LNG (fluid gas) terminal along the Croatian coast. In overall, co-operation 


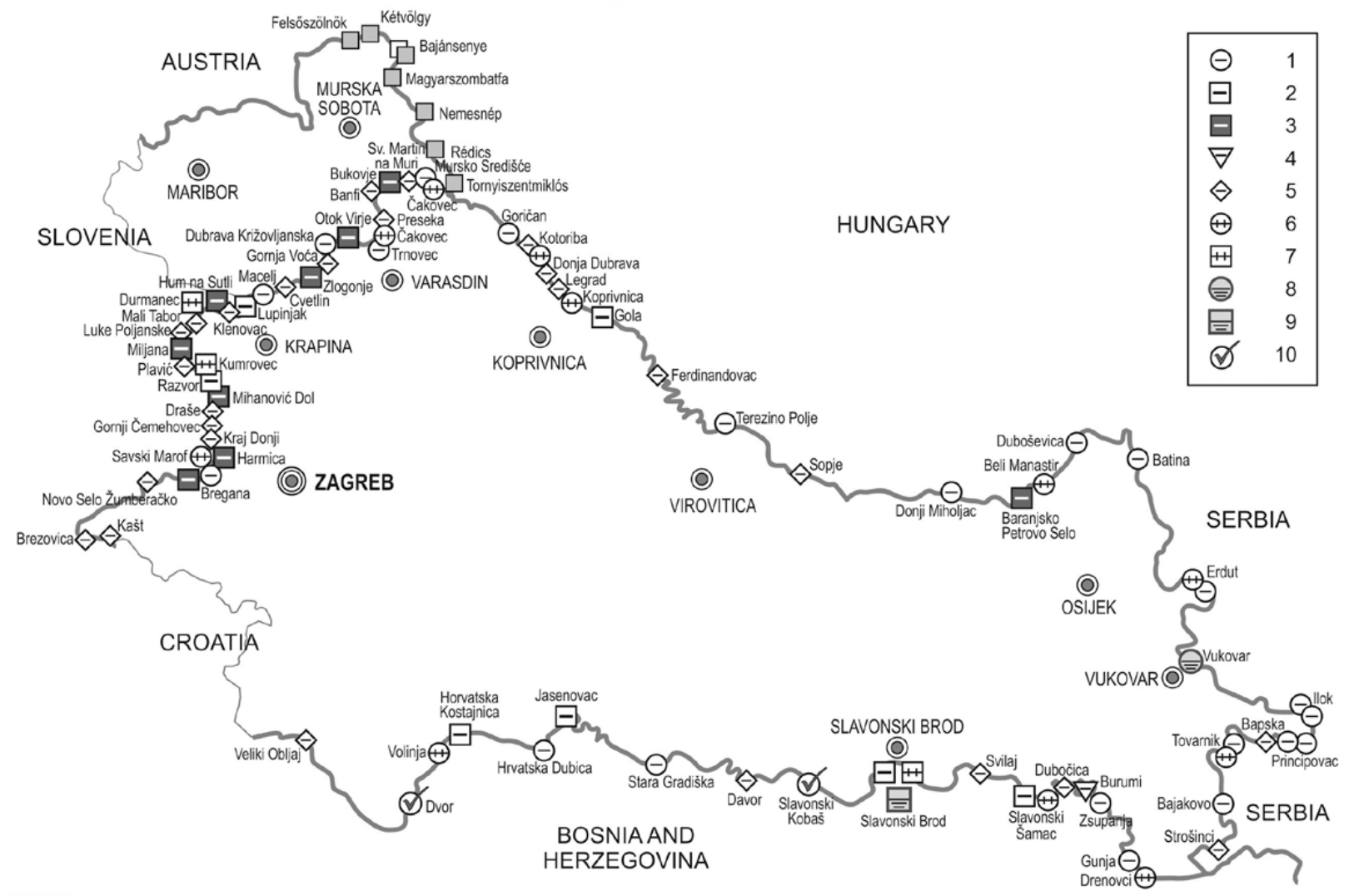

Figure 3. Border crossing points of Croatia, 2014

Legend: 1 - $1^{\text {st }}$ category permanent international public road border crossing point; $\mathbf{2}$ - $2^{\text {nd }}$ category international public road border crossing point; 3 - $2^{\text {nd }}$ category permanent interstate public road border crossing point; 4 - Seasonal public road border crossing point; 5 Permanent public road small border crossing point; $\mathbf{6}$ - $7^{\text {st }}$ category permanent international railway border crossing point; 7 - $1^{5 t}$ category permanent international railway border crossing point; 8 - $7^{\text {st }}$ category permanent fluvial border crossing point; 9 - $2^{\text {nd }}$ category permanent fluvial border crossing point; 10 - Temporary public road monitoring point.

Source: Carinska uprava Republike Hrvatske, 2014.

aims at the increased safety of energy supply and a more efficient utilisation of renewables.

The process of state formation in Croatia was more difficult and complex than in Slovenia due to the country's involvement in the civil war. Croatia embarked on the road towards Euro-Atlantic Integration only after the turn of the millennium following the internal political shift. The rate of FDI-inflow is consequently much lower than in Slovenia and the Visegrad Countries. On the basis of the data of the National Bank of Croatia, Hungary has been the $4^{\text {th }}$ largest investor in Croatia for nearly a decade, preceded by Germany, Austria and the Netherlands. Between 1993 and 2015, the total value of Hungarian capital investments amounted to 2.2 billion euros, which substantially exceeds the volume of Croatian FDI inflow in Hungary (34.3 million euros). The primary targets of Hungarian investments are financial, food industry, trade, energy and real estate sectors.

Nine-tenth of the foreign trade of Croatia is realised in European countries. Hungary is the sixth most significant partner of Croatia in terms of bilateral traffic. Growth in the trade in goods mainly originates from the energy sector (energy resources - MOL-INA, electricity - MVM-HEP). The rate of Croatian exports in manufactured products and non-consumable raw materials is significant in Hungary. A permanent problem in Croatian foreign is caused by the significant deficit, the value of imports exceeds twice the value of exports. The weakness of exports is a result of the outdated, belated investments, the relative scarcity of capital and the exchange rate of the kuna.

Tourism in Croatia is a top-priority national sector disposing of significant traditions. According to the tourism satellite accounts of the past few years, this sector accounts for nearly one-fourth of domestic GDP and $27-29 \%$ of total employment. Despite the diversity of assets (national parks, world heritage sites, thermal waters), the vast majority of domestic and foreign tourism ( $95 \%$ of guest nights) is permanently concentrated in the Adriatic area. The guest turnover of the touristic region of Central-Croatia is connected to the capital city. The role of Hungarian tourist arrivals was predominant in the touristic linkages. Hungary occupies the 9th-1oth position in terms of the number of visitors arriving to Croatia and the num- 
ber of guest nights as well. Following a period of decline caused by the crisis, the rate of Hungarian visitors has been augmenting since 2011, and 2015 was a record year in terms of the number of guest nights. From the perspective of Hungary, competition between the Adriatic Sea and the Balaton is an interesting issue in the area of tourism. The declining number of guest nights of Hungarian tourists in Croatia is due partially to the crisis and partially to the introduction of the Széchenyi Card.

The development of economic ties is a highly prioritised element of European co-operation programmes. In the 2007-2013 programming period the tasks of the previous funding programmes were delegated to the IPA. Slovenian-Croatian and Hungarian-Croatian cross-border programmes were characterised by joint implementation and a shared allocation of ERDF and IPA funds. In Croatia the role of co-operation with EU member states is outstanding both from the aspect of the amount of external funding, the number of projects and collaborating partners. The strengthening of bilateral programmes involving the rest of the countries is hindered by several factors such as lacking institutional conditions, low level of EU integration, an unfavourable socio-economic context and a lack of trust as well.
The IPA Adriatic Cross-border Co-operation Programme occupies a special place among the multilateral programmes. Projects realised in collaboration with EU countries are twice as valuable than in other relations. Areas with a stronger economy dispose of a competitive system of project activities. The project elaborating capacities of Hungarian counties situated along the border, especially Osijek-Baranya are significant and successful, $43 \%$ of obtained project funding in the two countries is realised in this area. This indicates the availability of potential and receptivity as well (Sumpor, et al., 2013; Rácz, 2014).

The Hungary-Croatia IPA Cross-border Co-operation Programme 2007-2013 was approved by the European Commission in 2008 with a total budget of EUR $52,443,00090 \%$ of the amount is available for developments, while $10 \%$ was earmarked for technical assistance. An important feature of the program was that the developments had to have positive effects on both sides of the border. Exact figures on the project shares were not put, however, the decision makers were aiming at the ideal balance of 50-50\%. Table 2 shows the territorial allocation ( $\mathrm{NUTS}_{3}$ ) of the amounts of community funding. It was calculated based on the corporate seat of the participating project partners. This, in

Table 2. Territorial allocation of the community funding according to the official address of the project partner in Hungary-Croatia IPA CBC Programme 2007-2013

\begin{tabular}{|c|c|c|c|}
\hline Name of NUTS3 region & $\begin{array}{l}\text { Contracted community } \\
\text { funding (EUR) }\end{array}$ & $\begin{array}{l}\text { Number of lead } \\
\text { partners }\end{array}$ & $\begin{array}{c}\text { Number of project } \\
\text { partners }\end{array}$ \\
\hline \multicolumn{4}{|l|}{ Eligible regions } \\
\hline Baranya megye & 15527294 & 62 & 66 \\
\hline Somogy megye & 3352681 & 18 & 28 \\
\hline Zala megye & 6020845 & 25 & 45 \\
\hline Međimurska županija & 5198372 & 10 & 49 \\
\hline Koprivničko-križevačka županija & 3780201 & 13 & 48 \\
\hline Osječko-baranjska županija & 9264316 & 16 & 91 \\
\hline Virovitičko-podravska županija & 3413623 & 14 & 35 \\
\hline \multicolumn{4}{|l|}{ Adjacent regions } \\
\hline Bjelovarsko-bilogorska županija & 50920 & - & 4 \\
\hline Požeško-slavonska županija & 41367 & - & 2 \\
\hline Varaždinska županija & 210901 & - & 10 \\
\hline Vukovarsko-srijemska županija & 110942 & - & 4 \\
\hline \multicolumn{4}{|c|}{ Other regions (corporate seat outside of programming area) } \\
\hline Budapest & 1455522 & 3 & 4 \\
\hline Vas megye & 331009 & 1 & 2 \\
\hline Veszprém megye & 678481 & 4 & 5 \\
\hline Tolna megye & 159925 & 1 & 1 \\
\hline Grad Zagreb & 3079728 & 2 & 12 \\
\hline Istarska županija & - & - & 1 \\
\hline Sisačko-moslavačka županija & 1589986 & 1 & - \\
\hline
\end{tabular}

Source: Author's own calculations based on Hungary-Croatia Cross-border Co-operation Programme Project Database. 
several cases, does not necessarily correspond to the place of utilization, especially in case of de-concentrated public authorities and other organisations, such as development agencies, waterworks, infrastructure developing corporations, chambers, national radio associations, mine action centres, universities, schools. $55 \%$ of the beneficiaries of the projects were the Eastern counties. Based on the average amount of support per capita the figures in Somogy and Zala counties are remarkably low, which phenomenon is due to the relatively short border section and the dominance of small scale projects - the major investments in infrastructure were carried out in other regions (Csapó, et al., 2015).

The number of the partners participating also shows the unambiguously higher activity and more projects mean a higher number of partners. Figure 4 displays the intensity of cross-border cooperation. The relative (between settlements) and absolute (total number of the given settlement's relations) number of partnerships established within the single projects is a particularly good indicator of the region's morphological specificities outlined above: the direct border region is relatively weak, the distantly located cit- ies are dominant. Among the beneficiaries there are local governments, associations, civil society organizations, just as educational institutions. Considering the territorial deviation smaller municipalities close to the border were characterized by civil society activity, while - moving away from the border - the dominance of larger organizations and institutions can be found.

The two main priorities of the program were "Sustainable Environment and Tourism" and "Co-operative Economy and Intercommunity Human Resource Development". Table 3 shows the allocation of the amounts of support by Priorities / Areas of intervention / Action. The most support was allocated for priorities 1.1.1 and 1.2.2. Evaluating the program we can say that from the viewpoint of program content established, partnership structures and direction it has reached, moreover, in some dimensions exceeded the similar cooperation between member states. The program was in line with the European Criteria, priorities and the goals were synergistically adjusted to the national and regional documents. As the only negative feature of the program we need to highlight the weakness of the development's complexity and the

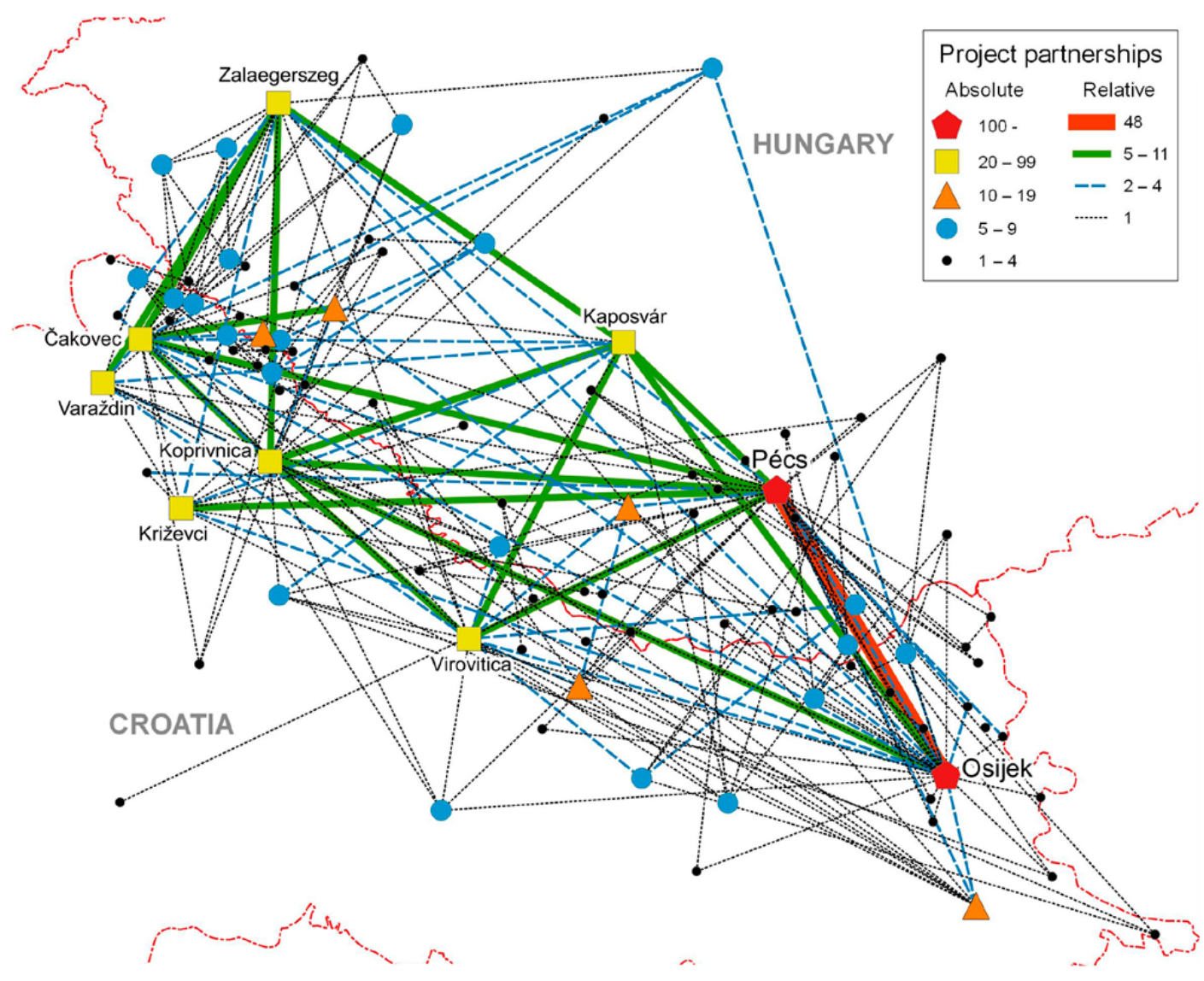

Figure 4. Partnerships in Hungary-Croatia IPA CBC Programme 2007-2013

Notes: The relative (between settlements) and absolute (total number of the given settlement's relations) number of partnerships established within the single projects.

Source: Author's own construction. 
Table 3. Allocation of the community funding by priorities in Hungary-Croatia IPA CBC Programme 2007-2013

\begin{tabular}{|c|c|c|c|c|}
\hline \multicolumn{2}{|c|}{ Priority / Area of intervention / Action } & $\begin{array}{l}\text { Contracted } \\
\text { community } \\
\text { funding (EUR) }\end{array}$ & $\begin{array}{l}\text { Total reimbursed } \\
\text { community } \\
\text { funding (EUR) }\end{array}$ & $\begin{array}{l}\text { Contracted/ } \\
\text { reimbursed (\%) }\end{array}$ \\
\hline \multicolumn{5}{|c|}{ Priority 1 Sustainable Environment and Tourism } \\
\hline \multicolumn{5}{|c|}{ 1.1 Sustainable and Attractive Environment } \\
\hline 1.1 .1 & $\begin{array}{l}\text { Development of landscapes in the Mura-Drava- } \\
\text { Danube area and its natural and rural surroundings }\end{array}$ & 11514903 & 10704983 & 93.0 \\
\hline 1.1 .2 & $\begin{array}{l}\text { Environmental planning activities and minor public } \\
\text { actions to improve the quality of the environment in } \\
\text { the natural areas }\end{array}$ & 3007913 & 2610667 & 86.8 \\
\hline \multicolumn{5}{|c|}{ 1.2 Sustainable Tourism in the Mura-Drava-Danube River Area } \\
\hline 1.2 .1 & Elaboration of a regional tourism product plan & 349995 & 332077 & 94.9 \\
\hline 1.2 .2 & $\begin{array}{l}\text { Development of infrastructure for active and } \\
\text { ecotourism: visitor centres, forest schools, water sport } \\
\text { infrastructure, bicycle routes, trekking-hiking paths, } \\
\text { rentals }\end{array}$ & 15587364 & 14810462 & 95.0 \\
\hline 1.2 .3 & Thematic routes of cultural heritage & 5192437 & 4358877 & 83.9 \\
\hline 1.2 .4 & Promotion of the river area as a single product & 846122 & 767635 & 90.7 \\
\hline 1.2 .5 & Private investment attraction & 279622 & 218464 & 78.1 \\
\hline \multicolumn{5}{|c|}{ Priority 2 Cooperative Economy and Intercommunity Human Resource Development } \\
\hline \multicolumn{5}{|c|}{ 2.1 Co-operative Economy } \\
\hline 2.1 .1 & Cross-border business partner finding & 1533464 & 1264650 & 82.5 \\
\hline 2.1 .2 & Cross-border labour market mobility promotion & 1209289 & 1020836 & 84.4 \\
\hline 2.1 .3 & Joint research, development and innovation & 5380807 & 4382644 & 81.4 \\
\hline 2.1 .4 & Joint local planning, strategies, programmes & 2736042 & 2348471 & 85.8 \\
\hline \multicolumn{5}{|c|}{2.2 Intercommunity Human Resources Development } \\
\hline 2.2 .1 & $\begin{array}{l}\text { Joint cross-border education and other training } \\
\text { projects between educational institutions }\end{array}$ & 4089977 & 3529161 & 86.3 \\
\hline 2.2 .2 & People to people actions & 1918071 & 1609633 & 83.9 \\
\hline 2.2 .3 & Bilingualism actions & 620110 & 458494 & 73.9 \\
\hline \multicolumn{2}{|l|}{ Total } & 54266115 & 48417054 & 89.2 \\
\hline
\end{tabular}

Source: Author's own calculations based on Hungary-Croatia Cross-border Co-operation Programme Project Database.

lack of regional and sectorial harmonization. This is mainly due to the fact that the majority of projects can be interpreted as starting point. These are the initiatives, which presumably would not have been established without the support (Csapó, et al., 2015; Varjú, 2016).

Considering that half of the $355 \mathrm{~km}$ long state border is constituted by fluvial frontiers (Drava $135 \mathrm{~km}$, Mura $45 \mathrm{~km}$, Kerka stream $1.8 \mathrm{~km}$ ), the immediate border region is relatively scarcely populated, and over the past century, few investments have been realised, therefore it represents a significant natural value (Danube-Drava National Park, Mura-Drava Regional Park, Kopács Meadow Natural Park). The enclave nature of the border was thus favourable from the aspect of the utilisation of the environment. From this stems the outstanding opportunity to exploit the region's touristic potential. The rate of unexploited potential is high in the entire area (Slavonia receives only $1.3 \%$ of the guest turnover of Croatia, and merely $0.1 \%$ of the international guest nights). The predominance of the presence of waters necessitated a certain degree of cooperation between states in the extensive watershed area, albeit the viewpoints concerning water management and utilisation were frequently diverging. Croats prioritised the energy and economic utilisation of the Drava during the 1990s, while the Hungarian government cancelled the agreement with Yugoslavia and showed a preference for its natural protection related utilisation. Nevertheless, successful co-operation targeting water management and environmental protection was realised mainly in the framework of crossborder projects. The most successful among these is undoubtedly the Mura-Drava-Danube Cross-border UNESCO Biosphere Reserve extending to the area of five countries jointly initiated by Croatia and Hungary in 2009, and formally realised on 12 July, 2012 (Varjú, et al., 2014). 


\section{The „soft" structures of relations: culture, nationalities, sister cities}

Regarding cultural and ethnic relations, the situation of Hungarians living in Croatia and Croats living in Hungary are worth highlighting. The proportion of Hungarians living in Croatia resembles in size that of Croats living in Hungary, i.e. 0.3 percent of the total population. The relationship between the ethnic pattern and administrative state borders and the situation of settlement areas are relevant factors in the study of crossborder relations. The ethnic spatial pattern will not be discussed in detail in the framework of the current paper, only some specifics will be mentioned. Bilateral minority policy has constituted an element of bilateral political relations from the beginning, the legal situation of Hungarians living in Croatia and Croats living in Hungary can be regarded as fundamentally settled. The Constitution of Croatia recognizes Hungarians as a constitutive minority, which authorizes them to delegate an elected representative to the Croatian Parliament. Minority rights are partially based on the Fundamental Treaty of 1992 and partially on the Framework Agreement signed in 1995, wherein the contracting parties guaranteed the safeguarding of minority culture, languages, religion and identity (Act No. XVI of 1997). Its implementation is monitored by the HungarianCroatian Joint Committee on Minorities, which holds yearly sessions and drafts reports and proposals as well.

The role of cultural and educational institutions is fundamental in the practical achievement of these objectives. Both permit its citizens to conduct their studies in each others' language from the nursery to the university (as a mother tongue, on a bilingual or a complementary basis). Croatian language education is available in two secondary schools which also fulfil a role of educational centres: in Budapest (Croatian Kindergarten, Primary school, Secondary School and Student Residence) and in Pécs (Miroslav Krleža Croatian Kindergarten, Primary school, Secondary School and Student Residence). The University of Zagreb has operated a Hungarology Department since 1994, Osijek Josip Juraj Strossmayer University has operated a Hungarian Language and Literature Department since 2007. In Hungary, Croatian language and literature training is available in three cities: Budapest (ELTE BTK Department of Slavic Philology), Pécs (PTE BTK Department of Croatian language and literature) and Szombathely (NyME SEK Department of Croatian language and literature). It must be highlighted that the Croatian Theatre in Pécs maintained by the municipality and state funding is the only Croatian language theatre outside the borders of Croatia, thus it also serves the promotion of identity and fulfils the role of a cultural centre.
Formalised co-operation between municipalities constitutes a special form of cross-border relations. In the Hungarian-Croatian border area, nearly 70 Hungarian and the same number of Croatian municipalities dispose of a sister settlement on the other side of the border. Sister city relations are alive and operating in most cases. Among these, the Mohács-Beli Manastir and the Pécs-Osijek partnerships have the longest history, their sister city contracts were signed in 1970 and 1973, respectively. The number of sister city contracts augmented in the independent state of Croatia due partially to the circumstances in the aftermath of the South Slav war (such as the reception of fleeing families), the minority living in diasporas abroad, and the influence of the processes of Europeanisation. The most recent researches conducted in the borderland demonstrate that municipal leaders identify the same possible and significant areas of co-operation in both countries: infrastructure, tourism, education, culture. Nearly half of the municipalities are planning to increase the intensity of their partnership ties, mostly in the framework of personal meetings between settlement leaders and citizens and touristic settlement marketing (Keller, et al., 2015).

\section{Conclusion}

Both countries have experienced profound mutations concerning their ideas on borders over the past 25 years, which resulted in the strengthening of crossborder relations and the enrichment of the cooperation by a specific geopolitical and minority policy element. From the aspect of cross-border cooperation, the underdeveloped state of the borderland and its unfavourable economic and demographic processes are of crucial importance. Among the spatial structural specifics, special attention must be given to the unique geographic position of the countries at the intersection of peripheral regions with the fluvial frontier also serving as a dividing boundary along the majority of the border section. Cross-border cooperation in the immediate proximity of the state border can only be detected in two areas (Barcs-Virovitica, Slovenian-Croatian-Hungarian tri-border area), resulting in the predominance of cooperation between relatively remote nodes (Pécs, Osijek). The relatively small size of the countries in question and their centralised state organisation leaves its mark on the co-operations. Interstate political relations are therefore essential from the perspective of cross-border relations.

As a brief summary of cross-border relations it can be stated that a collaboration between local (crossborder) stakeholders is most evident in the case of soft structures. Broadly interpreted cultural relations are its strongest elements. Scientific collaborations 
are external finance-dependent. Economic co-operations are weak. The problems are more or less similar. Cross-border co-operation is hindered by converging price levels and the fact that there is no shortage of goods, the same products and services are accessible on both sides of the border. The overvaluation of the kuna has been maintained, the exchange rate of the Forint is stable. Albeit Croatia has not become a member of the Schengen area with its EU accession, border crossing has been considerably sped up, due partially to the obliteration of customs controls and partially to the common one-stop passport control system. Poor language skills are still a significant obstacle.

Everyday life provides the issues to be examined as a possible continuation of the research: how are language skills manifested in the shaping of relationships? To what extent have EU funds contributed to the co-operations? What potentials does the Dravaregion contain? Where does the MOL-INA-affair lead and what constitutes its background (nationalism, geopolitics)? To what extent did the refugee crisis damaged relations and how are they resolved? What are the consequences of the technical border closure despite the fact that no fence was built along the Drava? A demand for partnership can be detected in a number of areas and the survival of certain historical traditions - a millennium of coexistence and cultural proximity - is also discernible.

\section{Acknowledgements}

Research for this publication has been supported by $\mathrm{Na}$ tional Research, Development and Innovation Office NKFIH grant \#NN 114468 (Change and Continuity in Hungarian Spatial Imaginaries: Nationality, Territoriality, Development and the Politics of Borders).

\section{References}

Bali, L. 2010. Two micro-regional cases of the Croatian-Hungarian cross-border cooperation, Barcs and Hungarian-Croatian-Slovenian triborder example. Térés Társadalom 4, 237-248. (in Hungarian with English summary)

Bali, L. 2012a. The present and future of Croatian-Hungarian cross-border relations. Underground Kiadó, Budapest-Szepetnek. (in Hungarian with English summary)

Bali, L. 2012b. The major political aspects of the Croatian-Hungarian relations in the changing geopolitical space, in the Carpathian-Balkan Region. Podravina 11, 26-35.

Čelan, T. J. 2014. A Historical Geographical Analysis of the Development of the Croatian-Hungarian Border. Modern Geográfia 4, 75-92.
Csapó, J., Čelan, T. J., Trócsányi, A. 2015. The effects of cross-border co-operation on regional development on the example of the Croatian-Hungarian border zone in the light of EU programming. Területfejlesztés és Innováció 2, 22-31. (in Hungarian)

Egyházy, Z. 2013. Feasibility Study Level Investigation of the Border Crossing Sections of Projects Related to the Transport Operational Programme and the Examination of their Network Effects on the Hungarian Border Sections. Hungarian Transport Administration, Budapest. (in Hungarian)

Fábián, A. 2013. Constructivist Views of Cooperation along the Border. Acta Universitatis Sapientiae Economics and Business 1, 35-47.

Gulyás L., Bali, L. 2013. From the Coexistence of Border Zones to Integration: Characteristics of Croatian-Hungarian Border Relations from 1945 until Today. Eurolimes 16, 13-26.

Hajdú, Z. 1996. Emerging conflict or deepening cooperation? The case of the Hungarian border regions. In: Scott J. W. et al. (eds.) Border Regions in Functional Transition: European and North American Perspectives on Transboundary Interaction. Institut für Regionalentwicklung und Strukturplanung, Berlin, 193-211.

Hajdú, Z. 2004. Renewal of cross-border cooperation along the Hungarian-Croatian border. In: Pavlakovich-Kochi V, Morehouse BJ, Wastl-Walter D (eds.) Challenged Borderlands: Transcending Political and Cultural Boundaries. Aldershot, Ashgate, 109-121.

Hajdú, Z., Bali, L., Zágorec-Csuka, J. 2013. State borders and cross-border relations after 1990. In: Hajdú, Z., Nagy, I. (ed.) Dél-Pannónia. Institute for Regional Studies Centre for Economic and Regional Studies of HAS, Dialóg Campus Kiadó, Pécs, 456-474. (in Hungarian)

Hajdú, Z., Nagy, I. 2006. Changing border situations within the context of Hungarian geopolitics. In: Scott, J. W. (ed.) EU Enlargement, Region Building and Shifting Borders of Inclusion and Exclusion. Aldershot, Ashgate, 65-80.

Hardi, T. (ed.) 2008. Transborder Movements and Relations in the Slovakian-Hungarian Border Regions. Centre for Regional Studies of HAS, Pécs.

Horeczki, R. 2014. The South-Transdanubien small towns in the light of the development plans. Deturope 3, 97-111. (in Hungarian with English summary)

Jeszenszky, G. 2002. Main directions of the Hungarian foreign policy in the last decade of the century. In: Pritz, P. (ed.) Magyarország helye a 20. századi Európában. Magyar Történelmi Társulat, Budapest, 169-184. (in Hungarian)

Juhász, J. 2011. Achieve and protect independence. Croatia, 1990-1995. História 5-6, 82-89. (in Hungarian) 
Keller, K., Svržnjak, K., Kaszás, N. 2015. The Model of the Success of Settlement Twinning in the Hungarian-Croatian Cross-Border Region. Deturope 2, 117136.

Kovács, S. Zs. 2014. Presence of Financial Servicers along River Drava. Deturope 1, 79-94. (in Hungarian with English summary)

Lőrinczné Bencze, E. 2011. The new dimensions in Croatia-Hungarian interregional relationship. In: Kozma G., ed., New Results of Cross-Border Co-Operation. Debrecen, Didakt Kiadó, 65-76.

Lörinczné Bencze, E. 2013. Practice and Theory of the Enlargement of the European Union - the Croatian Case. Budapest-Székesfehérvár, Aposztróf-KJF. (in Hungarian)

Lőrinczné Bencze, E. 2014. Hungarian-Croatian Bilateral Co-operations since 1990s. Prague Papers on The History of International Relations 2, 141-156.

Lörinczné Bencze, E. 2015. Croatia from the Declaration of Independence to the EU accession. Székesfehérvár, Aposztróf. (in Hungarian)

MÁV Zrt. Communications Directorate, September 29, 2015. (in Hungarian) https://www.mavcsoport. hu/mavinform/ausztria-fele-ujraindult-forgalomhorvatorszag-fele-nem-jarnak-vonatok

MÁV Zrt. Communication Directorate, March 7, 2016. (in Hungarian) https://www.mavcsoport.hu/mavinform/ujraindult-vonatkozlekedes-magyarorszag-es-horvatorszag-kozott

Nagy, I., Romelic, J. 2013. Regional Features of South Pannonia. In: Hajdú, Z., Nagy, I. (ed.) South Pannonia. Institute for Regional Studies Centre for Economic and Regional Studies of HAS, Dialóg Campus Kiadó, Pécs, 475-531. (in Hungarian)

Nagy, I. 2013. Natural Features and Resources of the region. In: Hajdú Z., Nagy, I. (ed.) South Pannonia. Institute for Regional Studies Centre for Economic and Regional Studies of HAS, Dialóg Campus Kiadó, Pécs, 87-123. (in Hungarian)
Paasi, A. 2012. Commentary. Border Studies Reanimated. Going Beyond the Territorial/Relational Divide. Environment and Planning A 44, 2305-2309.

Press conference of Miro Kovač and Péter Szijjártó, February 2, 2016. http://www.kormany.hu/en/ministryof-foreign-affairs-and-trade/news/strategic-cooperation-is-in-the-interests-of-both-hungary-and-croatia

Press conference of Péter Szijjártó and Tomislav Karamarko, July 9, 2015. http://www.kormany.hu/en/ ministry-of-foreign-affairs-and-trade/news/hungarian-croatian-bilateral-relations-to-be-improved

Rácz, Sz. 2014. Regional development in Croatia from the turn of millennium to the EU accession. Regional Statistics 2, 71-86.

Scott, J. W. 2013. Territorial Cohesion, Cross-Border Cooperation and the EU's Political Identity. A Brief Observation. In: Pálné Kovács, I., Scott, J. and Zoltán, G. (eds.) Territorial Cohesion in Europe. Institute for Regional Studies Centre for Economic and Regional Studies of HAS, Pécs, 73-84.

Sokcsevits, D. 2011. Croatia from the Seventh Century up to the Present Day. Budapest, Mundus Novus. (in Hungarian)

Sumpor, M., Đokić, I., Žalac, G. 2013. Prospects of Croatian Regions in Western Balkan Territorial Cooperation. In: Pálné Kovács, I., Scott, J. and Zoltán, G. (eds.) Territorial Cohesion in Europe. Institute for Regional Studies Centre for Economic and Regional Studies of HAS, Pécs, 503-516.

Suvák, A. (ed.) 2014. General framework plan for the Drava region. DUPLO Hungary-Croatia IPA CBC Programme. Institute for Regional Studies Centre for Economic and Regional Studies of HAS, Pécs.

Varjú, V. 2016. Environmental cohesion across the Hungarian-Croatian border. Bulletin of the Serbian Geographical Society 1, 81-92.

Varjú, V., Suvák, A., Dombi, P. 2014. Geographic Information Systems in the Service of Alternative Tourism - Methods with Landscape Evaluation and Target Group Preference Weighting. International Journal of Tourism Research 5, 496-512. 